\title{
Mycoplasms in bovine lymphocyte cultures
}

\author{
B. MAYR, J. FLATSCHER and G. THIEMANN \\ Institute of Animal Breeding and Genetics \\ and Institute of Bacteriology, \\ Vienna University of Veterinary Medicine, Linke Bahngasse II, A-rozo, Wien, Austria
}

Lymphocyte cells taken from A. I., bulls were cultured in conventional, 3-day cultures. Conventional staining was performed. The cultures were inocculated with 4 -mycoplasma strains, isolated from A.I. bulls. Inocculation with $10^{6}-\mathrm{ro}^{8} \mathrm{CFU}$ had to be broken off because of insufficient mitosis results. Inoccula of $\mathrm{IO}^{2}-\mathrm{IO}^{3}$ showed mitosis inhibitative potencies, varying with the strains. None of the isolates caused significant frequency increases of breaks compared to the controls.

\section{Report on chromosomal examination of A.I. bulls in Hungary}

\author{
A. KOVACS and M. PAPP
}

Central Station for Artificial Insemination, Budapest, Hungary

In preliminary studies the karyotypes of I $\mathrm{I}$ bulls were prepared at the Department of Pathology, Robert Károly Hospital, Budapest using a modified human method.

The routine chromosomal examinations started practically at the beginning of r975. Till now, altogether II 6 bulls were evaluated in three A.I. stations, most of them (ro4) at our Institute. Ill bulls were found to be phenotypically normal and 5 showed chromosomal anomalies. All bulls belonged to six pure breeds and three crossed ones. The number of bulls in each breed is as follows: 36 Hungarian Simmenthal, Io Austrian Simmenthal, 46 Holstein Friesian, I Dutch Red-White, I Swedish Friesian, 3 Hereford; Io Hungarian Simmenthal $\times$ Holstein-Friesian, 8 Holstein-Friesian $\times$ Jersey $\times$ Hungarian Simmenthal and $I$ German Friesian $\times$ HolsteinFriesian.

Of the nine breeds examined chromosomal anomalies were found only in the Hungarian Simmenthal and Holstein-Friesian breeds. In Hungarian Simmenthal two cases of centric fusions I /29 and II/I 6 and one chimerism of sex-chromosomes, in Holstein-Friesian breed one case of mosaicism I $3 / 21$ and one chimerism of sex-chromosomes were disclosed. According to these findings the percentage of chromosomal anomalies in the two breeds abovementioned were 8.33 p. cent and 4.34 p. cent respectivelly.

\section{Ergebnisse von zytogenetischen Routineuntersuchungen an Bullen in Bayern}

\author{
G. STRANZINGER \\ Aus dem Lehrstuhl für Tievzucht der Technischen Universität München, \\ Freising-Weihenstephan, R.F.A.
}

Seit 1973 wurden in Bayern 533 Besamungsbullen (36,9 p. cent aller eingesetzten Bullen) aus 8 von I 3 Stationen untersucht. 6 heterozygote Translokationsträger wurden in 2 von 4 untersuchten Rassen gefunden. Der Anteil von I, I3 Prozent an Zentromerfusionstieren in Routineuntersuchungen entspricht nicht der tatsachlichen Verbreitung der Zentromerfusion in der Population, da die männlichen Tiere aus gezielten Paarungen selektiert werden, jedoch einzelne positive Vererber als Translokationstiere in der künstlichen Besamung stärker als der Durchschnitt eingesetzt wurden. Zusätzlich konnten 5 Chimaren mit mehr als 80 p. cent weiblichen Zellen ermittelt werden, wovon nicht bei allen die heterosexuelle Zwillingsgeburt bekannt war. 